\title{
Specialevejledning set indefra og udefra
}

\author{
Anmeldelse af Gitte Wichmann-Hansen
}

Leth Andersen, Hanne \& Wirenfeldt Jensen, Tine. Specialevejledning - rammer og roller. En universitetspadagogisk undersøgelse. København: Forlaget Samfundslitteratur, 2007.

Hanne Leth Andersen (professor i universitetspædagogik) og Tine Wirenfeldt Jensen (amanuensis) har skrevet en aktuel og relevant bog om specialevejledning. Bogen er baseret på afrapportering og diskussion af en kvalitativ undersøgelse ved Det Humanistiske og Det Teologiske Fakultet på Aarhus Universitet. Forfatterne har interviewet 7 studieledere, 21 vejledere og 21 specialestuderende og nyuddannede kandidater fra syv forskellige fag ved de to fakulteter. Undersøgelsen har særligt fokus på de forskellige aktørers kendskab og holdninger til vejledningens rammer og retningslinjer, både som de er opstillet af det enkelte fag og af den enkelte vejleder. Ud fra disse interviews har forfatterne udkrystalliseret en række temaer omkring vejledning, som de deler med læseren både gennem konkrete interviewcitater og teoretiske refleksioner. Bogen er i den forstand ikke en lærebog, men en erfaringsbaseret debatbog.

Et interessant hovedresultat fra undersøgelsen er, at selvom flere studienævn har udarbejdet retningslinjer for specialevejledning, er disse ikke altid alment kendte eller implementerede $\mathrm{i}$ den enkelte vejleders praksis. Ydermere viser undersøgelsen, at der blandt vejledere og studerende er stor forskel på kendskabet til og interessen for de opstillede rammer og regler for vejledningen. Disse fund perspektiveres $i$ bogen ud fra læringsteoretiske vinkler, ligesom fundene også underkastes en interessant diskussion i forhold til universitetskultur og -ledelse.

Bogens styrke er, at den er empirisk funderet og samler konkrete erfaringer og ideer fra eksisterende vejledningspraksis. Det er en styrke, dels fordi der findes bekymrende lidt empirisk forskning om akademisk opgavevejledning i Danmark, og dels fordi bogen skaber et vigtigt udgangspunkt for universitetspædagogisk udviklingsarbejde ved at give stemme til dem, der dagligt varetager vejledningen. Ydermere er det en styrke, at interviewene er kildetrianguleret, så vejledning både belyses indefra (dvs. gennem vejledernes tanker om egen praksis) og udefra (dvs. via de studerendes personlige oplevelser og studieledernes overordnede, ad- ministrative vinkel). Det giver læseren overbevisende indsigt i vejledningens idiosynkratiske natur, præget af mange varierende, personlige og kontekstuelle faktorer. En svaghed ved undersøgelsen er, at den begrænser sig til interviewmetoden, hvilket er et kritikpunkt, man også kan rette mod den eksisterende internationale forskning på feltet. Hvis der skal produceres ny substantiel viden på vejledningsområdet, er der brug for mere avancerede designs med anvendelse af multiple metoder.

Bogen afsluttes med en række vigtige anbefalinger til, hvordan vejledningen på universiteterne kan udvikles $i$ fremtiden. Her bærer bogen dog præg af, at dens erfaringsgrundlag er humanistiske fag.Vejledere på især naturvidenskabelige og sundhedsvidenskabelige uddannelser vil nok skulle igennem lignende undersøgelser for at afdække, hvordan de kan udvikle deres områder. Bogen henvender sig dog til alle, der er involveret $i$ vejledning, og kan med fordel læses af alle, der arbejder med pædagogisk udvikling og kvalitetssikring $i$ universitetsverdenen.

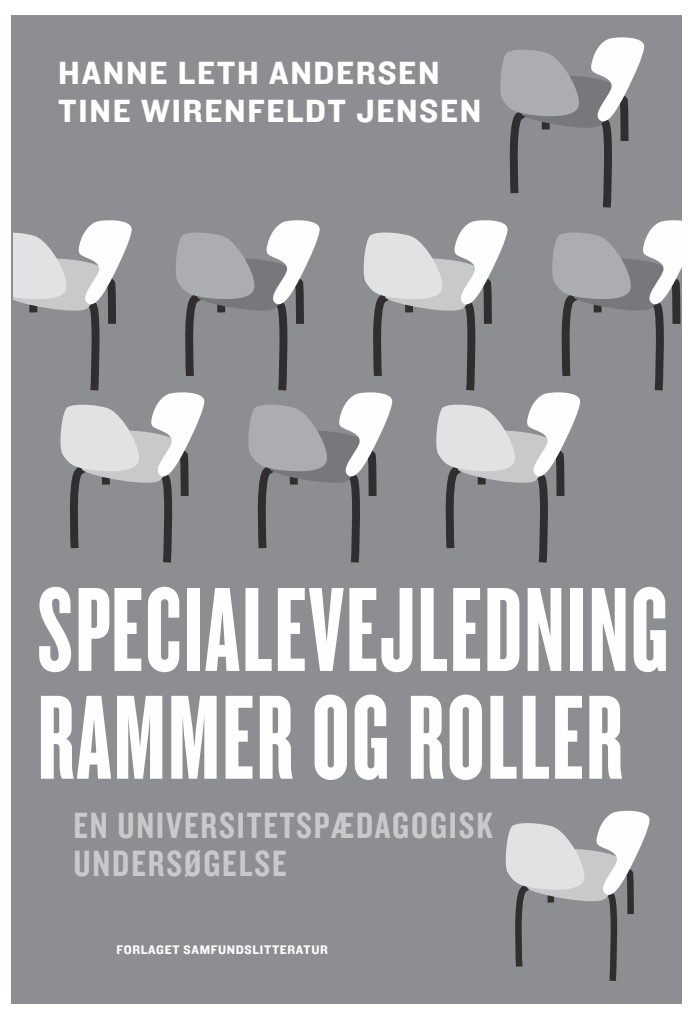

